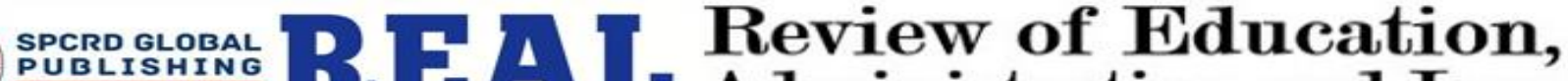 Sustainable Solutions 1 Administration and Law \\ Journal homepage: http://real.spcrd.org ISSN (Print): 2708-1788 \\ ISSN (Online): 2708-3667
}

\section{Theme of Isolation and Child versus Adult Feelings: Stylistic Analysis of Alice Munro's Short Story “The Eye”}

\author{
${ }^{a}$ Fozia Chandio, ${ }^{b}$ Zia Ahmed, ${ }^{c}$ Akbar Sajid \\ ${ }^{a}$ Lecturer in English Literature, Institute of English Language and Literature, University of Sindh, Pakistan \\ Email: Fozia.chandio@usindh.edu.pk \\ ${ }^{\mathrm{b}}$ Principal, Govt. Emerson College, Multan, Pakistan \\ Email: zia.ahmed@gecmultan.edu.pk \\ ${ }^{c}$ Chairman Department of English, NUML Multan Campus, Multan, Pakistan \\ Email: masajid@numl.edu.pk
}

\begin{tabular}{l}
\hline ARTICLE DETAILS \\
\hline History: \\
Accepted 12 Nov 2020 \\
Available Online 31 Dec 2020 \\
\hline Keywords: \\
Alice Munro, Short Story, \\
Stylistics Analysis, The Eye, \\
Leech and Short \\
JEL Classification: \\
R53, R59
\end{tabular}

DOI: $10.47067 /$ real.v3i3.94

\begin{abstract}
Analysis of the stylistics features of any author has been very interesting technique to explore themes depicted by him/her. This paper examines a short story of Alice Munro titled 'The Eye', from stylistic perspective. 'The Eye' is the opening tale of the set of four stories, in a style of memoir that is titled as 'Finale'. This set of four stories appears in her collection of short stories titled "Dear Life" (2012. ) The paper presents the stylistics analysis of the story keeping the stylistic approach in focus suggested by Leech and Short in Style in Style in Fiction (2007). The story is analyzed stylistically in terms of character and characterization, point of view and speech, thought and writing presentation. Stylistic study of any text effectively provides comprehension of the base of the text particularly and its evaluation generally (Peer 2008). In order to carry this out, the method of textual analysis of Qualitative research approach is conducted. The end of the analysis is to have a turnout of a deeper comprehension of the relationship between style and literary aesthetics in 'The Eye' by studying the stylistic patterns behind Munro's narrative, in order to find out her creative approach. Paul Simpson maintains, "Stylistics serves to inquire into the language of the text and on a broader level to investigate creativity in the use of language (2004:3). The endeavor made in the paper explores that Munro has an ambivalent and complicated technique of presentation, both structurally and thematically. Here, the argument is that the stylistic analysis of the story reveals that Munro has high artistic approach towards the short story; she narrates the fiction with such an ambiguous approach that it welcomes more than one interpretations of the story.
\end{abstract}

(C) 2020 The authors. Published by SPCRD Global Publishing. This is an open access article under the Creative Commons AttributionNonCommercial 4.0 


\section{Introduction}

Alice Munro (born 10 July 1931) is a Canadian English-language Nobel Laureate; author of short stories. Munro started writing in very young age. Dance of the Happy Shades (1968) earned her high praise in world of literature, which was her debut in literature of the short story. She has been receiving a number of honors and awards including Nobel Prize in Literature in 2013. Munro was declared as "master of the contemporary short story" at the time of Nobel Prize ceremony. Her stories are taken as the literature that depicts everyday life. Majority of her stories are set in small town Huron County, Ontario, sketching simple folks of the town. Her art of storytelling is usually appreciated for its characteristics of clarity and psychological realism. In History of Canadian Literature, W. H New declared Munro's short stories as “embed more than announce, reveal more than parade" (New 2003), the phrase is famously used now in connection to her short stories. Up till now she has done with some fourteen collections of short stories including the latest one Dear Life (2012).

Dear Life (2012) is the most recent and probably the last collection of stories by Alice Munro set in her region the small Ontario town of Canada. Four of the stories in the end 'The Eye', 'Night', 'Voices' and 'Dear Life' collectively titled as 'Finale' draw autobiographical sketches of the author, of which she says in its Forward, "are not quite stories" rather they are "autobiographical in feeling, though not, sometimes, entirely so in fact," and she adds: "I believe they are the first and last - and the closest things I have to say about my own life" (Munro 2012). Hence, those include four amazing autobiographical ones give readers peeps into her childhood. Many of the stories in this collection are set in a place around Lake Huron which depicts the surroundings in brilliant manner that the places can be imagined vividly.

Regarding Munro's style in these stories, Charles Mcgrathm, in his article published in The New York Times on November 16, 2012, submit that Munro's stories have a particular style which reveals chronic chronology where they observe beginning at the end and end sometimes in the middle. She once said that she reads in the same manner not following sequence; this style exhibits her view of the world in which things are not in order rather merely happen, all at once and the way they cannot be explained (Mcgrathm 2012).

\section{2. 'The Eye' (The Story at a Glance)}

'The Eye' is the opening story of the four autobiographical stories collectively called 'Finale'. The story is set in small town southwestern Ontario in Canada during Great Depression in1930. The story begins when young Alice Munro is five years old. She recalls when she was five years old there came in their family a new member- a baby boy and that she was told by her mother that she wanted brother. Arrival of another baby after the first one set the same atmosphere for her for again she was convinced with same justification. Whether it was so or not is not clear to the little girl but her trust for her mother is clear. As she said that she never felt out of the way her mother explained she feels usually (Munro 2012). But one thing is clear that her mother played an authoritative role in her life. She writes that her home was completely filled with the feelings attached to her mother e.g. her sound, her footsteps, even there is her smell at the place where she is not physically present. Things change in mother-daughter relationship with the arrival of more siblings; and at very young age girl started realizing that her mother's concept about her is completely changed from her own. The girl was opened and frank with only a person named Sadie who was appointed by her mother to house chores. She started spending time with her, sometimes helping her in house chores. Alice Munro gives short but vivid information of the character of Sadie at this point; though later reveals major fact of her life. Sadie was the person who was considered by her town people as the 'celebrity' (ironically). She was working at a station for radio, she also could play with musical instrumental devices and sing her vocals for 
welcoming and fare-welling functions; the songs were her own composition. People, except those living on the farms in the town, were least interested in both her program and the small station. They made fun of her. These people were fond of listening popular songs and war news played at Toronto Stationthe bigger one. However people living at the farm were fond of listening to her songs; although she sang the songs that reflected isolation, pain and misery. Both Sadie and girl develop a close bond. The mother noticed girl's intimation with Sadie and pointed that they talk too much when they are together. By the time reader comes to know one more fact about Sadie that she was a self-identified person who did not want any authority over her or to say more exactly she did to please herself whatever she did. The text exhibits that she went for dancing; she went by herself and for herself. She said". As the story moves, the reader is confronted with two dancing halls-one in town, the small one, where Sadie danced and the other was out of town on the highway. The place was called the Royal-T. Besides, the character sketch of both women-mother and Sadie, is vividly portrayed through text along with all other descriptions like that of dancing halls. The incident in the story occurs very slowly and slightly even in such a manner that reader wouldn't guess or expect such striking change in the story. One night Sadie is killed in an accident outside Royal-T following a dance; though the source of the incident is not mentioned. Even why she goes to dancing is also not revealed. Reader comes to know all this when our little narrator is brought to Sadie's coffin in Sadie's house. The story turns to a turning point with the event of Sadie's death. Munro is taken her dead body by her mother in order to show her the reality of death. At that time Alice was very young. The mysterious thing happens when she looks at Sadie's face lying in a coffin; Sadie's eye flittered into the casket. This is something gothic when a young child observes death so closely. The sight of the scene is moving and depicted in a bewitching style of presentation.

\section{Style and Literature}

Style is the way or form in which an author presents his or her point of view before audience particularly it focuses on diction and imagery employed. It can be termed as the literary language of the author in a piece of literature. It is this style, in which language is presented, that play paramount role in the piece of literature in appealing the audience and making the case or declaration more emphatic. The focus is primarily on the applications of devices-linguistic, to the text. Rebecca Rozmiarek in Persuasive Writing tells that stylistic devices are used with an unavoidable intention that straight goes to impress the readers or audience (2000:84). The best triumph of the author can be found in the way he blends his artistic ability with scheme of language available so as to achieve certain aesthetic effect. Therefore, to digest a text, both -literary or artistic expertise and linguistic proficiency, are essential standards. Thus, Stylistics analysis of any piece of literature cannot be acclaimed as autonomous devoid of any other aspect. It, rather, is related, one way or other, with the language setting of the author. John Povey in his article produces the view in a way that, "A sensitive stylistic analysis of a text can produce facts about its linguistics organization which cannot be ignored"( Povey 1990). Stylistic analysis of the any piece of literature is as old as literature itself. It developed with the reader's quest for understanding the message of the author which he puts before the reader through varied devices applied in literature. Stylistic analysis has a key role in evaluating and interpreting the literature. The basic feature of any piece of literature is text and text is comprised of language. Hence in interpreting the text its linguistic aspect keeps greater weight to be interpreted. Stylistics analysis declares how language, vocabulary and syntax work in a text. It is the language that drags readers of the fiction into its fictional globe. This invented imaginary world of the text is a verbal world that is declared all the way long through the words in which it is represented. Therefore, in order to understand and analyze fiction, a detailed rather deep investigation and analysis of language is an obligatory precondition.

Stylistic analysis varies in full range to that of literary criticism which appreciates the quality of 
a work of art in a different manner then Stylistics analysis involves. Literary criticism appreciates and judges by commenting on the work hence it involves, to its full, the external perceptions of the critics; on such grounds as: the personal and or cultural significance of the themes; whereas the stylistics analysis provides the literary criticism with primary stage of understanding the text. "The purpose of stylistics is not confined with the exploration of style and manner of an author's literary piece rather it goes beyond that and relates to the effect of literary piece. It explores the significance of interpretation through linguistics features (Wales, 2001). Therefore Stylistic analysis gives the access to the reader or critic to the deeper understanding of the message of the text. Thus stylistic analysis aims to find out the literary devices and techniques used in text. The aim of the stylistic analysis is to evaluate not only the quality of a text but the meaning of a text also.

\section{Theoretical Framework}

Leech and Short presents the method of analysis of the literary piece providing certain criterion. The proclaimed that the stylistic studies through the help of linguistic features help reader in understanding and interpreting the text effectively. They suggest that the points of view-both fictional and discourse, indicate the significance of the voice of the story that determines the vision of the story. Apart from the importance of Point of view, the analysis of the conversation behavior of the character (s) is helpful in comprehending the character as an individual and relation with the co-characters. Another feature which is involved in analysis is the way writer presents that vision through different literary techniques.

\section{Discussion}

The analysis of the text of the story is based on the features mentioned above. Each feature is explored separately and keeping the features in background the story is analyzed. The theme of child isolation and adult feeling versus childhood feeling are rendered through these stylistics features.

\subsection{Theme of Childhood versus Grown up Feelings}

The story has very brilliantly rendered the theme of how an individual as a child feels and how the feelings change when the individual is grown up. The depiction is extra-ordinarily bewitching as it comes from the autobiographical touch of the author. Munro says about the finale of the collection that these "are not quite stories" rather autobiographical in feelings. Hence they succeed in capturing the attention of the reader to great extent. Consequently the theme of child feelings versus adult feeling impresses with its autobiographical aspect.

This theme revolves around the text as the narrator explicitly expresses what little Alice feels at the time of her childhood and those feelings change when she is grown up. At initial stage she believed in everything that her mother proclaims to her. But later with the passage of time she realizes at the very young age that her notions are different from what her mother hold for her. And her awareness that "she is a separate individual than what her mother expects her" grows stronger as she grows younger.

She sees at Sadie's funeral that Sadie, though lying dead moved her eyelid to Alice; she started believing this as true at that time but at the young age she realizes it was nothing but a fragment of her imagination as the result of her strong bond with the dead.

She realizes that 'to grow is to be sad', growing is intensively associated with the sadness; for she used to believe abruptly to the notions surrounding her when she was child. She did not question anything and believed in everything but with the passage of time she experiences differently and she 
comes to know that things are not as simple as they seem to be; in consequence she changes her notion of "believing in everything" into "not believing anymore"

Munro brilliantly makes a reader experience what her characters are going through especially little one. She shows up the gradual transformation of her character from her dependent thinking into an independent thought. In short Munro explicitly turns towards the theme of how and what a child feels and how her insight and way of perceiving things changes.

\subsection{Theme of Isolation}

The story reveals the relationship of a daughter and mother in very complicated terms. In terms of their attachment which is uncommon, the characters act unusually. There is some agitation and trouble in their relation because of the complexity in both characters. The mother always inflicts her own propositions upon her daughter which averts Alice's own capability of having ideas. Simultaneously the mother shapes her daughter's character the way she wants not taking notice of what the daughter wants. She does not try to understand what she wants what she feels or what she desires. Even she stops her to be mingled with society and keep friendship. As a result she does not have "any town friends at Sunday school." Paradoxically she does not welcome Alice's father interference in their lives. With the arrival of her baby brother Alice realizes that her mother is no longer the same kind and soft, ironically her mother tells her that she wants a brother; the fact of which she is unsure. This notion further sharpens the isolation of Alice. Her mother did not pay the heed she always wanted. "No time for her to manage that anymore." She starts to be reserved even towards her mother. With this external conflict between the two, her isolation grows stronger and stronger with the birth of the second brother. And consequently she sets her lonely world apart.

Things change when her babysitter named Sadie is assigned their household duties. Alice becomes attached with her to kill her loneliness. By the time she starts adoring her; which is disliked by her mother as she finds her daughter has replaced her with Sadie. Even she does not like music yet she enjoys Sadie's singing to compensate her need of attention from her mother. Her separate world from her mother sets her as she expresses, "something in me was turning traitorous, though she didn't know why, and I didn't know why either."

The narrator signifies that a mother-daughter relation is as sensitive and complex as it seems serene and quiet. This for the major part leads a child to isolation.

\subsection{Characters and Characterization}

There are three dominant characters in the story. Alice herself, her mother and Sadie- all women characters. Munro's characters are ambiguous and vague. Sadie seems to be a mysterious woman whose complete identity is not shown or even her introduction is incomplete. She is presented with the attribute which are a complete contrast with the mother of Alice. She is an assertive and influential person. She is a confident, spirited and cheerful girl who loves to talk about herself. She is completely involved in her own world with her own view of the world. She does not welcome any judgment, criticism or changes by anyone else rather she is happy with what she is and how she is doing. She is a good singer though she is not much appreciated by town people but people from the farm are fond of her songs as she sings traditional old songs of sadness and isolation.

Sadie's nature makes Alice attached to her extremely. She is adored by little girl. This connection is unusual; which fills a gap for the child's loneliness. 
Another character is Alice's mother who is quite a committed, resolute and fully fledged individual. Before her maternity she used to teach. She is an independent woman with a complete outlook as a lady of the house. She is a complex character who develops complexity by default in her daughter's nature. She hold her own propositions upon her daughter without taking care of her daughter's feelings and thoughts. She feels insecure when she realizes that her daughter is being too attached with her babysitter. She is a mild yet hard character; kind yet unkind, possessive yet indifferent. Author's handling of this character with so much contradictory attributes is noteworthy and significant.

Little Alice is depicted as a very complicated child as her mother defines her. Alice herself expresses that her brother will not grow as complicated as she is; and that he would be a normal one. She is shown as unclear and disordered about herself that whether she is a good girl or the other way round. She recognizes her isolation and her mother's indifferent attitude towards her. She even though recognizes her attributes yet she is less expressive. She has been raised very reserved. She is restricted to home not making friends anywhere.

All these characters are different from one another and hold the attributes which are contradictory. They perceive the world differently yet hold some connection amongst them. Mother is possessive of Sadie for her strong bond with her daughter yet she takes her daughter to show up her dead body not caring of how her baby would feel. Sadie on the other hand is not mother of Alice in spite of that she possesses those motherly attributes in her nature which move Alice towards her. Alice though quite understands the situations and her mother yet remains silent and inexpressive.

Author's handling of these characters is commendable. She has touched upon a sensitive topic of a mother-daughter relation, the isolation of a child, child's adoration for the lively babysitter, with so delicate yet intricate manner.

\subsection{Point of view}

Leech and Short put forward two points of view; fictional point of view, and discourse point of view. The first suggests the view point of one character or many, the later offers the analysis of the relationship between the narrator and the fiction. Although the analysis of the teller and tale is crucial part of the analysis in fiction. In “The Eye” Munro's point of view is presented through direct narration and active verb as dominant. The narrative is first person narrative.

The fictional point of view identifies Alice a child of nine years old as the narrator of the story. Since this is first person narrative so the author has used 'I'. The characters are shown and perceived through her point of view. This is autobiographical in feelings with dominant factor of feelings hence does not involve the smooth storyline.

As far as the discourse point of view is concerned, 'The Eye' is a direct address to reader. Reader is addressed many a times through story with the word 'you', which enhances the interest of reader. The narrative mode is 'Narrative Voice' and 'Narrative point of view'; where the first person pronoun 'I' is used by narrator for herself 'you' for reader and third person pronoun for the characters in the story, although this is clear; yet the narrative is both structurally and thematically complicated and hence invites many readings.

The story does not end with the simple point of view rather it invites many interpretations. It does not end smoothly rather involving the complex storyline ends with the questions and confusions 
for reader. The beginning seems to be the end, while the end seems to be the beginning.

\subsection{Writing Presentation}

Writing presentation is important aspect of the stylistic study of any piece of literature. In Munro's The Eye the style is subtle with sudden and unexpected change in theme. Munro does not give a bit of hint what the next would occur but it occurs with stunning revelations leaving reader in shock or surprise. Munro's is a non-transparent inexplicable text leaves you to ponder over what you read and explore inside why it was written.

Such atmosphere is maintained through some sort of suspense; and through her craft of hiding information from reader at many stages (later revealing). Sadie is introduced with half information about her that she works at radio station but her regular visits to small dancing hall or her frequent visit to Royal-T(another dancing hall perhaps more dangerous one) is not revealed to reader at the first stage of her introduction. Another instance of this discovery is that reader is not aware of the fact that Sadie had left Alice's house work long before her death. It is only revealed after her death almost in the end of the story. Munro's this style of writing certainly serves provision of dramatic trace to story. Such trace arouses strong emotions in the reader.

\subsection{Gothic Element}

'The Eye' may be recognized with Alice Munro typical mode of Southern Ontario Gothic-a subgenre of Gothic fiction mainly associated with Alice Munro. This exemplifies twice in the story; first with the scene of Sadie's coffin and movement of her dead eyelid which is felt by little Alice and which is dreadfully presented to reader, when Alice was looking at the face of dead body of Sadie, "Something moved. I saw it, her eyelid on my side moved. It was not opening or halfway opening or anything like that but lifting just such a tiny bit as would make it possible, if you were her, if you were inside her, to be able to see out through the lashes. Just to distinguish maybe what was light outside and what was dark".

Another feature of gothic element is involved in the scene of Sadie's accident which arouse pity and fear. The scene is described with clear-cut information of her accident that she was hit by car on her way back home from the dance hall she worked "Sadie had been killed when walking home from the Royal-T dance hall. A five years old girl's first observation of death is also characterized by some gothic arousal. Thus the existence of gothic elements of a fiction is evident through text.

Ambiguity is one of the major elements that reader observes in the text. Sometimes it seems that every bit is significant in story. Many a time questions emerged in reader's mind from reading this story. And the story does not answer them not even a hint of an answer. For example it is known that Sadie is killed in a car accident but from where the information of her accident is taken is not clear. Another example of obscurity is in the character of Sadie; we are not informed of why she goes to dancing halls! Thus the story seems incomplete. Munro expects her reader to simply accept and comprehend whatever and however it is. It seems she loves wordplay. This is quite a novelty on the part of Munro; that she puts her readers in the mysterious paradox leaving the story concealed in the thought to be interpreted at different level. Not only this, but the same vagueness is evident in the existence of characters also. The story has complicated characters like that of Sadie and Alice's mother. Sadie sang sad songs at radio but in home she was full of valor and vigor. As our narrator narrates, "Her voice was strong and sad and she sang about loneliness and grief with such sorrow in a fullthroated alto, but in her job with us she was full of energy and confidence". Her mother is also a complicated character; seems to be stern in her behavior in the beginning and that sympathetic at the 
end. Sometimes she is seen trying to justify as to why things are like that way sometimes indifferent to how things go. In Munro's world, female characters are complex, not easily comprehendible. So in the story things characters actions leave certain queries in mind of which she does not seem to take pain to explain; as to her ambitions that are too high do not easily resolute.

The other major feature that looks obvious is its dreamlike or to say more exactly almost dreamlike fragmentary utterance of a memoire- like- story. More often it looks diary based material intrigued with some creative art of fiction. The text sounds flashbacks of Munro's notebooks more than a fiction based story.

\subsection{Poetic Touch}

Beside many a times text seems to be more poetic like rather than prosaic. There are various stages in the text which give impressions of lyrics and verses or blank verses e.g.

"Then my mother said something about it being better when school started. Something about me being better or something concerning Sadie that would be better. I don't want to hear."

At other place in the story the lines for instances present poetic touch and rhythmic notion,

"Now school has started. It started some weeks ago, before the leaves turned red and yellow. Now they were mostly gone”.

At some other place the text reads,

"If you were her, if you were inside her," "you" could "distinguish maybe what was light outside and what was dark."

Such art of expressions in story is certainly creative and novel which welcomes abruptly audience's attention and attraction.

\subsection{Allusions and Imagery}

The craftsmanship of novelty in style is evident in many ways. Munro's use of references and how she depicts images of scenes is worth noticing. In the story imagery is vividly presented. We are lead to sensing the things in a real manner for their bold and bright description. For instance the two dancing halls are portrayed in details with the living touch of imaging them. Sadie's accident scene and Alice and her mother's encounter with her dead body all depicted with some slight of terror as to arouse the manifestation of readers. Not only this, but there are various examples of such solid imagery in the text. Thus Munro's craft of imagery is praiseworthy without question. Her frequent use of references and allusions is so cunningly used that they seem to be a total part of the story rather than just outside references and enhance understanding of the reader of the characters situation. Moreover they are easy to spot. For example, Munro makes use of referencing Alice in Wonderland (1865 novel by Lewis Carroll, about a girl trapped into rabbit hole and adventures fantasies of the world of anthropomorphic creatures.) in order to give situation of little Alice in the story who falls in pitiful condition of saying yes no according to characters outside her own existence. Her direct references of the popular songs like 
'three little fishes and a momma fishy too' or

'leanin' on the old top rail, in a big corral.

Lookin' down the twilight trail for my long lost pal.'

And many other references and allusions are scattered throughout the text with an effective usefulness.

\subsection{Humor and Irony}

Munro's humor is found suddenly, but with full sentences. This is noticed in a scene at Sadie's house. Little girl sees two boys in there, "The younger one is stuffing a whole cookie into his mouth in a comical way and the other, older, one is making a disgusted face. Not at the cookie stuffer, but at me". Munro's tool of humor does not seem to be pointless; it seeks to serve a significant aspiration. For example girl's mother asks her about children that "but we do love them, don't we? Quickly I said yes. She said, "Truly?” She wasn't going to stop till I said truly, so I said it.”

The ironic touch is also given some share in the text. For example Sadie is considered a celebrity; now the word 'celebrity' is used in an ironic tone while Sadie is not liked or admired by the town people when she works at radio station. And many other examples of ironic tone are found.

\subsection{Euphemism}

Beside euphemism has also made its way into the text. At many places words are used in a soft tone but it seems the use of euphemism is very much significant. The word 'creamery' (Alice's mother told her that Sadie left house job and started working in a creamery), is used ambiguously because anything of her job in the creamery is maintained at no place in the story. May be the use of the word is just because of Alice's little age.

\section{Conclusion}

With the ultimate findings that this paper receives it can be concluded that Munro's mastery of short story combines all those fine techniques that are required to make a story appreciable and valuable. Her techniques of writing vary time to time in the story. To break the monotony of a serious subject a subtle implementation of humor is observed. In fact her craft of humor and irony is easily spotted. Munro's typical element of southern Ontario gothic is also analyzed through the text. Use of references and allusions is also found with certain meaningful purpose. Brilliant use of imagery determines real like impression of scenes e.g. locals and situations. Fine use of euphemism, with almost an ambiguous point, is noticed. In fact Ambiguity and vagueness prevails to such an extent that the text sounds complex utterance as a result it inwardly invites heavy interpretation. The text is a nontransparent inexplicable text that leaves you to ponder over what you read and explore inside why it was written. Above all Munro's art of well-crafted sentences is phenomenal. She can be considered an expert in art of exploring the thoughts of women with her wonderful dreamlike or to say more exactly almost dreamlike fragmentary utterance of a memoire- like- story which more looks material from diary that reveals that she has a deep insight into human relationships.

\section{References}

Jeffries, L., \& McIntyre, D. (2010). Stylistics. Cambridge University Press.

Leech, G. and Short, M. (2007). Style in fiction: A linguistic introduction to English fictional prose foreign language. (2nd ed.). U.K: Pearson Education Limited.

Mcgrathm, C. (2012). The Sense of an Ending: 'Dear Life,' Stories by Alice Munr. The New York Times. Munro, A. (2012). Dear Life. New York: Vintage Books.

New, W. H. (2003). A history of Canadian literature. McGill-Queen's Press-MQUP. 
Povey, J. (1990). Literature and Language Teaching by Christopher J. Brumfit and Ron A.

Carter. Issues in Applied Linguistics, 1(1).

Rozmiarek, R. (2000). Persuasive Writing: Grades 6-8. Teacher Created Resources.

Simpson, P. (2004). Stylistics: A resource book for students. Psychology Press.

The Nobel Prize in Literature 2013". Nobelprize.org. Nobel Media AB 2014. Web. 24 Jan 2016. <http://www.nobelprize.org/nobel_prizes/literature/laureates/2013/>

Van Peer, W. (Ed.). (2008). The Quality of Literature: Linguistic studies in literary evaluation (Vol. 4). John Benjamins Publishing.

Wales, K. (2001). A dictionary of Stylistics, 2nd edition, (Harlow: Longman) 